\title{
ÇATIŞMA ÇÖZÜMLERİ YAKLAŞIM VE YÖNTEMLERİNDE ŞİDDET İÇERMEYEN EYLEMLER VE TOPLUMSAL OLAYLAR
}

\author{
*Kenan DAĞCI \\ **Erkan BÜLBÜL
}

\section{Özet}

Şiddet içermeyen mücadele, şiddet kullanımını reddeden bir çatışma çözümü tekniğidir. Toplumdaki her bireyin katılabileceği, daha demokratik ve özgürlükçü bir sisteme sahip olmak gibi barışçıl amaçlar taşıyan ve bu amaca ulaşıldığında sadece mücadele edenlerin değil toplumun tamamı için kazançlar sunan bu teknik, şiddet içeren muadillerine göre toplum üzerinde daha etkili ve pozitif tesirlere sahiptir. Bu çalışmada daha demokratik ve özgür bir siyasi yapının oluşturulmasını amaçlayan toplumlarda, şiddet içermeyen eylemlerin siyasi iktidarla olan çatışma/ihtilaf çözümlerinde nasıl kullanıldığının analizi yapılmış ve bu mücadele tekniğinin toplumsal olaylarla ilişkisi incelenmiştir. Çalışmanın amacına ulaşmak için siyasi gücün doğası ve kaynakları hakkında araştırma yapılmış, şiddet içermeyen mücadele tekniğinin kullandığ 1 metot ve mekanizmalar anlatılmış ve şiddet içermeyen mücadelede stratejik planlamanın temel ilkeleri değerlendirilmiştir.

Anahtar Kelimeler: Şiddet İçermeyen Eylemler, Otpor, Çatışma Çözümleri

\begin{abstract}
Non-violent action is a form of conflict resolution technique that avoids usage of violence. In comparison with its equivalent techniques that use violence, non-violent action has more effective and positive impacts on society. It welcomes every individual in society to participate and has peaceful aim such as acquiring a more democratic and liberal system that not only the contenders of the action but all society would benefit from the results when acquired. In this study, it is analyzed that how non-violent actions are utilized to resolve conflicts or disputes against the government in a society that aims constructing a more democratic and independent political structure, and examined the relation of this struggle technique with social events. To achieve the aim of this study, nature and the source of the political power, the methods and the mechanisms of the non-violent action are explained, and fundementals of the strategic planning of non-violent action are evaluated.
\end{abstract}

Keywords: Nonviolent Actions, Otpor, Conflict Resolutions

\footnotetext{
* Prof. Dr., Yalova Üniversitesi İ̈BF Uluslararası İlişkiler Bölümü Öğretim Üyesi

${ }^{* *}$ Araştırmacı
} 


\section{Giriş}

Diktatörlük rejiminin zulüm ve baskısı altında yaşayan toplumlardaki bireyler, zayıflık ve özgüven eksikliği gibi nedenlerle, kural koyucu iktidara karşı olan rahatsızlıklarını dile getirmekten bile korkmakta, iktidardan kurtulmak için askeri darbe ya da uluslararası askeri müdahale beklemektedir. Fakat bu seçenekler var olan sorun için gerçekçi ve kalıcı çözümler sağlamamaktadır.

Askeri darbe diktatörden kurtulmanın en hızlı yolu olmasına karşın, yeniden oluşturulması istenen sistem ve toplum ile kural koyucu arasındaki güç dağılımının yapılması konularında yetkin kapasiteye sahip olmamaktadır. Askeri darbeyi yönetenler genellikle muhalefet partilerinin önemli isimleri ya da ordu ve polis kurumlarının üst düzey yöneticileri olmaktadır. ${ }^{1}$ İktidar koltuğunda yapılan bu değişiklik, toplumun çoğulcu siyasi gücünü ifade eden bir sistem değişikliğini içermediğinden iktidarın gücünü sağlamlaştırdıktan sonra önceki diktatörden daha sert ve zalim olması ile sonuçlanmaktadır.

Uluslararası müdahale ise yabancı hükümetler için ülkedeki baskıcı diktatör bahane edilerek farklı amaçlar ve hedefler için bu ülkeye girişimde bulunmanın meşru gösterilmesine, diktatörden kurtulduktan sonraki dönemde de ülkedeki ekonomik kaynakların kullanılması ve ülkenin askeri üs olarak faydalanılması sonuçlarını doğurmaktadır. ${ }^{2}$ Bir ülkedeki güçlü ve baskıcı bir rejimi yıkacak yeterli askeri kapasiteye sahip başka bir ülkenin rejim yıkıldıktan sonra kendi amaçlarını dayatacak yeterli güce de sahip olduğu göz önünde bulundurulmalıdır.

Diktatörden kurtulmanın en etkin ve sağlıklı yolu toplumun kendi kendini özgürleştirmesidir. ${ }^{3}$ Toplumun bu özgürleşme mücadelesinde, gaddarlık, işkence ve cinayetlerle yoğrulmuş ve güçlenmiş rejimin sadece şiddet kullanılarak bitirileceğinin amaçlanması yanlış bir seçenek olmaktadır. Rejim tarafından şiddet ve

\footnotetext{
${ }^{1}$ Sharp, Gene ve B. Jenkins; (2003), The Anti-Coup, The Albert Einstein Institution, Boston,s.7

${ }^{2}$ Sharp, Gene; (2010), From Dictatorship to Democracy: A Conceptual Framework for Liberation Fourth

Edition, The Albert Einstein Institution, Boston, s.5

${ }^{3}$ Sharp, Gene ve J. Raqib; (2009), Self-Liberation: A Guide to Strategic Planning for Action to End a

Dictatorship or Other Oppression, The Albert Einstein Institution, Boston.s.16.
} 
bask1 görmüş mağdurların öfkeleriyle beslenen direnme hırsı, direnişçileri çeşitli şiddet bazlı faaliyetlerle çözüm arayışına itmektedir. Fakat bu durum genellikle toplumun rejim tarafından öncekinden daha fazla şiddet ve baskıya uğraması ile sonuçlanmaktadır. Çünkü şiddet kullanarak karşı koyma tercihi, baskıcı rejimle her zaman en üstün ve donanımlı oldukları bir alanda mücadeleye girmek anlamına gelmektedir.

Yukarıda belirtilen nedenlerden dolayı askeri darbe, uluslararası müdahale ya da ülke içerisinde şiddet bazlı eylemlerle var olan rejimin ortadan kaldırılması ve yerine daha demokratik ve özgür bir yapının getirilmesi amacı gerçekçi ve elverişli olmamaktadır. Bahsedilen geleneksel yaklaşımlar genellikle çatışmaları bastırmak ya da karşılıklı ihtilafları azaltma ile ilgilenirken, 21. yüzyılda ortaya konmuş olan çatışma çözümleri yaklaşımları, sadece çatışmaları yönetmek yerine çatışmanın temel sorunları ve doğası üzerine odaklanmaktadır. ${ }^{4}$ Bu kapsamda sosyal, psikolojik, ekonomik metotlar ya da bunların kombinasyonu oluşturularak uygulanan şiddet içermeyen mücadele (nonviolent struggle) yakın geçmişte ve günümüzde savaş ya da diğer şiddet içeren yöntemlere alternatif olarak gösterilebilir. Şiddet içermeyen eylemleri diğer yöntemlerden ayıran en önemli özellik kötüye kötülükle karşılık verme ideolojisi üzerine kurulmamasıdır. ${ }^{5}$ Çatışma çözümlerinde kullanılan şiddet içermeyen mücadelenin öncülerinden Gandhi bu mücadele tekniğini “Büyük bir sevgi ve bir o kadar büyük bir direnme arzusunun kötülüğe karşı kombine edilmesi” olarak ifade etmektedir. ${ }^{6}$

Bu çalışmada şiddet içermeyen eylemlerin, toplumların daha özgür ve demokratik bir siyasi yapıya kavuşma arzularında nasıl modern bir silaha dönüştürülebileceğinin anlaşılması amacıyla aşağıdaki sorulara cevap aranacaktır.

- Şiddet içermeyen eylemler çatışma/ihtilaf çözümlerinde nasıl kullanılmaktadır?

\footnotetext{
${ }^{4}$ Dağc1, Kenan ve Efe Çaman; (2012), “Uluslararası Çatışma Çözümleri Yaklaşımları: Müzakere ve Arabuluculuk" / "Conflict Resolution Approaches: Negotiation And Mediation", International Joint Conference, 10th (Int.) Knowledge Economy and Management Congress, Istanbul.

${ }^{5}$ Sharp, Gene; (2003), There are Realistic Alternatives, The Albert Einstein Institution, Boston, s.4

${ }^{6}$ Gandhi, Mahatma; (1955), “My Religion”, http://www.mkgandhi.org/ebks/my_religion.pdf, s. 79, 08.03.2015.
} 
- Şiddet içermeyen eylemlerin toplumsal olaylarla ilişkisi nasıl açıklanabilir?

İki soru bağlamında bu çalışmanın temel varsayımı şiddet içermeyen eylemlerin topluma sundukları siyasi güç ile kullandıkları eylem metotları ve değişim mekanizmalarının çatışma/ihtilaf çözümünde etkili olduklarıdır. Bu varsayımda belirtilen değişkenlerin anlaşılması maksadıyla örnek olay/durum incelemesi olarak Sırbistan'da 2000 y1lında gerçekleşen toplumsal olaylar şiddet içermeyen eylemler bakımından incelenecektir. $\mathrm{Bu}$ nedenle çalışma üç bölümden oluşacaktır. Giriş kısmının ardından şiddet içermeyen mücadele kapsamında literatür incelemesi yapılmış ve çalışmada kullanılan metodoloji anlatılmıştır. İlk bölümde şiddet içermeyen eylemlerin önemli bileşenleri olan siyasi gücün yapısı, güç kaynakları ve bu kaynakların elde edilmesi için gerekli olan güç dayanakları hakkında teorik inceleme yapılmıştır. İkinci bölümde şiddet içermeyen eylem metotları ve değişim mekanizmaları anlatılmıştır. Son bölümde ise şiddet içermeyen mücadelede stratejik planlamanın temel ilkeleri üzerinde durulmuştur.

\section{Literatür İncelemesi}

Şiddet içermeyen eylemlerin çıkış noktası mevcut siyasi gücün ve kural koyucunun sorgulanması ve sistemin optimize edilmesidir. Toplumda şiddet içermeyen eylemlerin pasif direnişten ibaret olduğu algısının aksine, bu teknik aslında etkinlik ve eylemler üzerine kurulmuş ve strateji gerektiren metotlar içeren önemli bir mücadele aracidır.

Şiddet içermeyen eylemler savaş ya da diğer silahlı çatışma türlerine tam anlamıyla fonksiyonel bir alternatif olarak değerlendirilmektedir. ${ }^{7}$ Daha demokratik bir sistem için gerekli olan büyük bir siyasi değişiklik amacı güden toplumlar, şiddet içermeyen eylemler vasıtasıyla geçmişte önemli başarılar elde etmiştir. ${ }^{8}$ Hindistan'ın 1916 yılında başlayan ve 31 yıl süren bağımsızlık mücadelesi büyük ölçüde şiddet içermeyen eylemlerin sonucunda başarıya ulaşmıştır. Mohandas Gandhi, İngiliz hükümetinin kontrolü dışında kalan kurumlar oluşturarak hükümetin ülke içindeki

\footnotetext{
${ }^{7}$ Sharp, Gene; (2003), There are Realistic Alternatives, The Albert Einstein Institution, Boston,s.10.

${ }^{8}$ Sharp, Gene ve J. Raqib; (2009), Self-Liberation: A Guide to Strategic Planning for Action to End a Dictatorship or Other Oppression, The Albert Einstein Institution, Boston,s.11.
} 
egemenliğini zayıflatmıştır. Aynı zamanda insanların özgüvenlerini tekrar kazanmalarını amaçlayarak harekete geçmelerini sağlamış ve böylece toplumsal bir direnişle hükümete baskı uygulamıştır. Güney Afrika'da ise 1rk ayrımcılığı sorunu için neredeyse 10 yıl süren ve kararlı bir şekilde yürütülen şiddet içermeyen eylemler, 1990 yılında istenilen sonucun elde edilmesini sağlamıştır. Mücadelenin lideri olan Nelson Mandela bu dönemin büyük bir kısmında mahkûm olsa da, mücadelenin destekçileri tarafindan gerçekleştirilen protesto gösterileri ve grevler rejim üzerinde baskı oluşturulmasını ve bu sayede hakların eşitliğini garantiye alan yeni bir siyasi sistemin getirilmesini sağlamıştır. ${ }^{9}$ Polonya'da 1980 yılında yasal işçi sendikalarının oluşmasını amaçlayan grevlerle başlayan dayanışma mücadelesi, 1989 yılında Polonya Komünist rejiminin dağılmasıyla sonuca ulaşmıştır. Şiddet içermeyen mücadele 1989 yılında Çekoslovakya'da, 1991 yılında ise Doğu Almanya, Estonya, Litvanya ve Letonya'da komünist rejimlerin sonunu hazırlamıştır.

2000 yılında Sırbistan'da Miloseviç rejiminin sona ermesi olayı, şiddet içermeyen eylemlerin belirli bir strateji ve plan dahilinde gerçekleştirildiğinde mevcut rejimin gücü ve baskı mekanizmalarının kapsamı ne kadar etkili olursa olsun mücadelenin başarıyla sonuçlanabileceğinin ispatı niteliğindedir. Az sayıda üniversite öğrencisi tarafından Otpor adıyla kurulan grup, gerçekleştirdiği şiddet içermeyen eylemlerle toplumsal desteği arkasına almayı başarmış ve 2 yıl gibi kısa bir süre içerisinde yenilmez olarak görülen bir diktatörlüğün ülkedeki meşrutiyetini sona erdirmişstir. Sırbistan'daki bu mücadeleyi önceki şiddet içermeyen eylemlerden ayıran en önemli özellik uygulanan metot ve taktiklerin stratejik şekilde planlanmış olmasıdır. 1983'de Amerikalı Teorisyen Gene Sharp'ın katkılarıyla kurulan Albert Einstein Enstitüsü Otpor grubuna, siyasi gücün yapısı ve şiddet içermeyen eylemlerin temel ilkeleri konularında danışmanlık hizmeti vermiştir. $\mathrm{Bu}$ amaçla düzenlenen seminerlere öncülük eden Albert Einstein Enstitüsü'nden Amerikan ordusundan emekli Albay Robert Helvey "şiddet içermeyen eylemlerin Karl Von Clausewitzi" ifadesiyle Prusyalı ünlü askeri strateji uzmanına benzettiği Sharp'ın öğretilerini Otpor

\footnotetext{
${ }^{9}$ Popovic, S.,M. Andrej ve D. Slobodan; (2006), "Nonviolent Struggle : 50 Crucial Points", http://www.canvasopedia.org/images/books/50-Crucial-Points/NonViolent-Struggle-50-CP-booksmall.pdf?pdf=50CP-ENG, 09.03.2015.
} 
eylemcileriyle paylaşmıştır. ${ }^{10}$ Ayrıca bu dönemde Sırbistan kaynaklı bir sivil toplum örgütü olan Sivil Girişim Merkezi (Center for Civic Initiatives) Sharp'a ait olan Diktatörlükten Demokrasiye kitabının çeviri ve dağıtım görevini üstlenmiş, kitabın 5500 kopyasını Otpor ve o dönemin en önemli muhalif partisi olan Demokratik Parti üyelerine vermiştir. ${ }^{11}$ Gerçekleştirilen seminerler, çevirisi yapılan şiddet içermeyen eylemlere yönelik eserler ve hazırlanan eğitim kitapçıkları, Otpor eylemcileri üzerinde şiddet içermeyen mücadelenin temel esasları konusunda farkındalığın oluşmasına, bu sayede yapılan analizler ve stratejik planlar sonucunda baskıcı bir rejime karşı toplumsal bir silahın elde edilmesine imkân sağlamıştır.

Şiddet içermeyen eylemlerin Sırbistan'da sağladığı başarı birçok ülke insanı için ilham kaynağı olmuş, 2003 yılında Otpor'un önde gelen üyeleri tarafından kurulan Şiddet İçermeyen Eylem Stratejileri Merkezi (CANVAS) ve Albert Einstein Enstitüsü'nün danışmanlıkları aracılığıyla kendi mücadele gruplarını oluşturmuşlardır. Beyaz Rusya'da “Zubr”, Gürcistan'da “Kmara”, Kosova'da "Mjaft", Ukrayna'da "Pora" ve Mısır'da "Kifaye” sloganlarıyla oluşturulan gruplar şiddet içermeyen eylem tekniğini mevcut rejimlerini değiştirmek adına sosyal, psikolojik, ekonomik ve siyasi bir araç olarak kullanmıştır.

Beyaz Rusya, Burma, İran, Batı Papua ve Zimbabve günümüzde şiddet içermeyen eylem metotlarının kullanılarak otoriter rejimlere karşı mücadelenin devam ettiği ülkeler olarak bilinmektedir. ${ }^{12}$ ABD tarafından maddi olarak desteklenen Şiddet İçermeyen Eylem Stratejileri Merkezi'nin oluşturup internet üzerinden yayınladığı eğitim kitapçı̆̆ının başta İran olmak üzere birçok Ortadoğu ülkesinde yoğun olarak indirildiği belirtilmektedir. ${ }^{13}$

\footnotetext{
${ }^{10}$ Weissman, Steve; (2009), "How Washington Learned to Love Nonviolence", http://theragblog.blogspot.com.tr/2009/09/steve-weissman-how-washington-learned.html, 27.02.2015.

${ }^{11}$ Sharp, Gene; (2005), Waging Nonviolent Struggle: 20th Century Practice and 21 st Century Potential, Boston: Extending Horizons Books, s.321.

${ }^{12}$ Popovic, S.,M. Andrej ve D. Slobodan; (2006), "Nonviolent Struggle : 50 Crucial Points", http://www.canvasopedia.org/images/books/50-Crucial-Points/NonViolent-Struggle-50-CP-booksmall.pdf?pdf=50CP-ENG, 09.03.2015

${ }^{13}$ Birdişli, Fikret; (2013), "Şiddet İçermeyen Eylemler ve Ulusal Güvenlik", 118 Uluslararası Güvenlik ve Terörizm Dergisi, Y11: 2013, Say1: 4.
} 
Gelişen teknoloji şiddet içermeyen eylemlerin çehresini değiştirmekte ve bu çatışma tekniğini uygulayan mücadeleci grupların genellikle internet ve cep telefonu gibi iletişim araçlarını kullanarak, stratejilerini sosyal medya ile geniş kitlelere ulaşma üzerine kurdukları görülmektedir. Bu nedenle özellikle Ukrayna ve Gürcistan'daki devrimlere "e-devrim" de denilmektedir. ${ }^{14}$ Sosyal medyanın geniş kitlelere ulaşmada etkin olarak kullanılmasının ardından, ABD ve İsrail ordularının öncülük ettiği, son olarak da İngiliz ordusunun ülkelerdeki iç karışıklıkları bastırma yeteneklerini artırmak ve psikolojik savaşta kendisine avantaj sağlamak adına sosyal medya odaklı 'şiddet içermeyen özel kuvvetler' oluşturması şiddet içermeyen eylemlerin günümüzdeki önemini göstermektedir. ${ }^{15}$ (Guardian, 2015).

\section{Metodoloji}

$\mathrm{Bu}$ çalışma rejim baskısı altında yaşayan ve daha demokratik bir siyasi yapının oluşturulmasını amaçlayan toplumlarda gözlemlenen geleneksel şiddet bazlı çatışma yöntemlerine alternatif olarak şiddet içermeyen eylemleri incelemektedir.

Çalışmanın amacı toplumun siyasi iktidarla olan ihtilaflarının şiddet içermeyen eylemlerle nasıl çözüme ulaştırılabileceğini açıklamaktır. Her toplum içinde bulunduğu siyasi çevrenin analizi ile oluşturduğu stratejik planı şiddet içermeyen metot ve mekanizmalarla yürüterek arzuladığı özgürlük ve demokrasiye ulaşma yetkinliğine sahiptir. Makalenin amacına ulaşmak için aşağıdaki sorular cevaplanmaya çalışılmıştır.

- Siyasi gücün doğası ve dinamikleri nasıl açıklanmaktadır?

- Şiddet içermeyen eylemler hangi metot ve mekanizmaları kapsamaktadır?

- Şiddet içermeyen eylemlerde stratejinin önemi nedir? Strateji oluşturulurken hangi temel ilkeler dikkate alınmalıdır?

\footnotetext{
${ }^{14}$ Kuzio, Taras; (2006), "Communist and Post-Communist Studies", http://www.elsevier.com/locate/postcomstud, 05.03.2015.

${ }^{15}$ Guardian; 2015, "British army creates team of Facebook warriors", http://www.theguardian.com/uknews/2015/jan/31/british-army-facebook-warriors-77th-brigade, 20.02.2015.
} 
$\mathrm{Bu}$ sorular kapsamında çalışmanın temel varsayımının açıklanabilmesi için üç değişken incelenecektir. Birinci değişken toplumun içinde bulunduğu siyasi gücün yapıs1; ikinci değişken uygulanacak olan şiddet içermeyen metot ve mekanizmalar; üçüncü değişken ise ortaya konulan stratejik plandır.

$\mathrm{Bu}$ çalışma iki tür veri üzerine oluşturulmuştur. Bunlardan ilki şiddet içermeyen eylemler üzerine yazılmış önemli eserler ve internet gibi ikinci derece kaynaklardan edinilen teorik bilgiyi kapsamaktadır. Veri kaynaklarından ikincisi ise çalışmada incelenen Surbistan'daki Miloseviç dönemini anlatan gazete arşivleri, makaleler ve Otpor'un önde gelen üyelerinin beyanatlarından oluşan sözel verilerdir.

\section{Siyasi Güç}

Şiddet içermeyen mücadelenin etkin olarak yönetilmesi ve hedeflenen vizyonun gerçeğe dönüştürülmesi için atılması gereken ilk adım gücün doğasını ve dinamiklerini anlamaktır. Güç şiddet içermeyen mücadelenin tamamlayıcı unsurudur. Burada bahsedilen güç, sosyal ve siyasi gücü temsil etmektedir. Sosyal güç, bir grubun davranışlarını direkt ya da dolaylı olarak kontrol etme kapasitesidir. Siyasi güç ise hükümet, devlet ya da muhaliflerin siyasi amaçlarına ulaşmak için kullandığı araçların, etkilerin ve baskıların bütününü içeren bir tür sosyal güçtür. ${ }^{16}$ Böyle bir güç hedeflere ulaşmak için ödül ve yaptırımlar uygulanarak direkt olarak kullanılabileceği gibi gücün varlığından kaynaklanan kapasitenin etkisiyle dolaylı olarak da kullanılabilir.

Siyasi güce sahip olma ve bu gücü yönetme düşman ya da muhalif olan karşıt gruplardan doğan tehditlerin ortadan kaldırılması ve bu grupların gücünün kontrol altında tutulması için gereklidir. Temelde siyasi güce ulaşmak için benimsenen iki yaklaşım bulunmaktadır. Birinci yaklaşım toplumda yaygın bir görüş olan, aynı zamanda birçok düşünür ve siyasetçinin de siyasi güce ulaşmak için kaçınılmaz gördüğü şiddet bazlı eylemlerdir. Mao’nün “Siyasal iktidar silahın namlusu ile büyür" ve Stalin'in "Yumurtaları kırmadan omlet yapamazsınız" söylemlerinde de

\footnotetext{
${ }^{16}$ Sharp, Gene; (1973a), Power and Struggle (Politics of Nonviolent Action, Part 1), Porter Sargent Publisher, Boston.
} 
belirtildiği gibi siyasi gücün şiddet ve baskı ile büyüyen ve belirginleşen bir olgu olduğunu destekleyen ve siyasi gücü elde etmek, korumak ve artırmak için şiddet kullanımının en önemli ilke olduğunu savunan şiddet bazlı modelde siyasi gücün özgür ve adil yapılan seçimlerle elde edilmediği açıtır. Siyasi gücün elde edilmesinde benimsenen bir diğer yaklaşım ise şiddeti Jorge Luis Borges'in tanımladığı gibi zayıflığın son sığınağı olarak görenlerin ve devletin şiddet içermeyen mücadele ile şekillenmesi gerektiğini savunanların benimsediği şiddet içermeyen modeldir.

Sharp siyasi gücün temelini tekil ve çoğulcu iki model üzerinden tanımlamıştır. Tekil model, insanların mevcut sistemin iyi niyet, karar ve desteğine bağlı olduklarını kabul etmektedir. $\mathrm{Bu}$ modelde siyasi gücün masif taştan yapılmış piramidin dayanıklılığına sahip olduğu öngörülmektedir. Sistem değişikliği hükümdarın öldürülmesi, askeri darbe ya da yıkıcı sonuçları olan geleneksel savaş gibi şiddet bazlı eylemlerle sağlanmaktadır. $\mathrm{Bu}$ nedenle bu model etkin baskı ve kontrol mekanizmalarına sahip şiddet içermeyen eylemlere açık değildir. ${ }^{17}$ Çoğulcu modelde ise tekil modelin aksine hükümetlerin ya da diğer yönetim sistemlerinin toplumun rızası, kararları ve desteğine bağlı olduğu bir yaklaşım benimsenmektedir. $\mathrm{Bu}$ modelde iktidarın elinde bulundurduğu siyasi güç tamamen toplumun işbirliği ve desteğiyle sağlanan güçle doğru orantılıdır.

Bu ilk değişken kapsamında siyasi gücün yapısı; otorite, insan kaynakları, bilgi ve beceriler, materyal kaynakları, manevi faktörler ve yaptırımlar gibi güç kaynakları ve itaat kavramı ile ilişkilendirilerek açıklanacaktır.

Siyasi gücün doğası ve dinamikleri tekil ve çoğulcu olmak üzere iki model üzerine kurulmuştur. Tekil model güç olgusuna kendi kendine varlığını devam ettiren, sağlam, kontrol edilmesi veya yok edilmesi mümkün olmayan bir açıdan bakmaktadır. Tekil modelde gücü yöneten kişiler çeşitli nedenlerden dolayı değişse de, otoriter güç yapısı aynı kalmaktadır. Bu teori, insanların gücü yönetenlere ve onların kararlarına mutlak itaatle bağlı olduklarını varsaymaktadır. Şekil: 1. 1' de

\footnotetext{
${ }^{17}$ Sharp, Gene; (1973a), Power and Struggle (Politics of Nonviolent Action, Part 1), Porter Sargent Publisher, Boston, s.8-10
} 
gösterildiği üzere siyasi gücün tamamı kurulan otoriter yapının en üst kademesinde toplandığı, toplumun koyulan kurallara hiçbir girdisinin olmadığı ve sadece bu kurallara mutlak itaat etmesi gerektiği bir model oluşturulmuştur. ${ }^{18}$

\section{Şekil 1. 1: Siyasi Gücün Tekil Yapısı.}

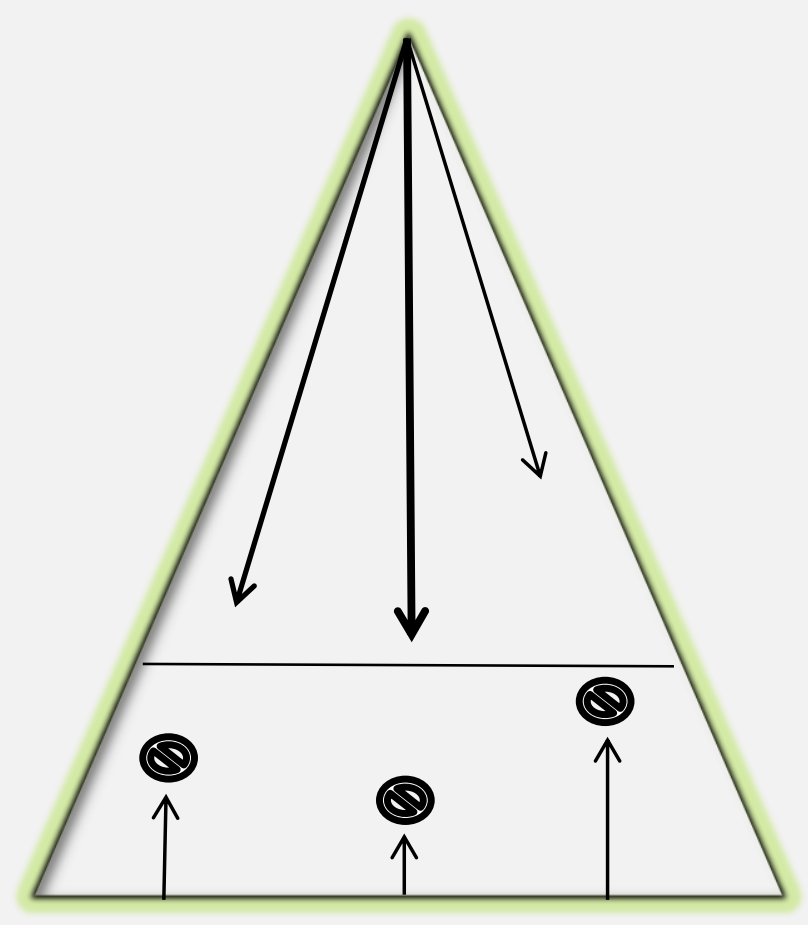

Kaynak: Helvey ( 2004: 167)

Bazen bu değişmez güç yapısının yönetenleri seçimle belirlenmektedir. Fakat yapılan seçimlerin özgür ve adil olduğu söylenemez. Stalin' in 'Seçimlerde oyları kimin verdiği değil, kimin saydığı önemlidir" sözüyle dile getirilen yaklaşım otoriter rejimlerde yapılan seçimlerin gücü elinde bulunduranların seçimlere hile karıştırdığını ortaya koymaktadır. Seçimlerde hile yapılarak elde tutulan bu güç bazen yanlış hesaplar nedeniyle şiddet içeren sonuçlar meydana getirmektedir. 1990

\footnotetext{
${ }^{18}$ Helvey, L. Robert; (2004), On Strategic Nonviolent Conflict : Thinking About The Fundamentals, The Albert Einstein Institution, Boston, 167.
} 
yılındaki Burma askeri rejiminin kontrolünde yapılan seçimde hile yapılmasına rağmen yanlış hesaplama ile seçimin kaybedilmesi ve sonrasında seçmenlerin beklentileri reddedilerek, muhalif liderlerin tutuklanması bu duruma örnektir. ${ }^{19}$

Çoğulcu modelde ise sağlam ve değişmez güç yapısına sahip olan ve gücün en tepede toplandığı tekil modelin aksine hükümetlerin ya da diğer yönetim sistemlerinin toplumun rızası, kararları ve desteğine bağlı olduğu bir yaklaşım benimsenmiştir. $\mathrm{Bu}$ modelde güç toplumun değişik kesimlerinden yükselmektedir. Kurallar toplumun rızası ve işbirliğiyle oluşturulmaktadır. Bazen bu işbirliği zorlama ve baskı ile olabildiği gibi bazen de toplumun çeşitli nedenlerden dolayı itaat etmesinden kaynaklanabilmektedir. Çoğulcu model siyasi gücün dayanımı ve varlığında gerekli olan kaynaklar için her zaman toplumun desteğine ihtiyaç duyulduğu ve güç yapısının değişken ve hassas olduğu varsayımı üzerine kurulmuştur.

Şekil 1. 2: Siyasi Gücün Çoğulcu Yapısı.

\footnotetext{
${ }^{19}$ Tonkin, Derek; (2004), "The 1990 Elections in Myanmar (Burma): Broken Promises or a Failure of Communications?”, http://www.ibiblio.org/obl/docs/DT-Elections.html, 02.03.2015
} 


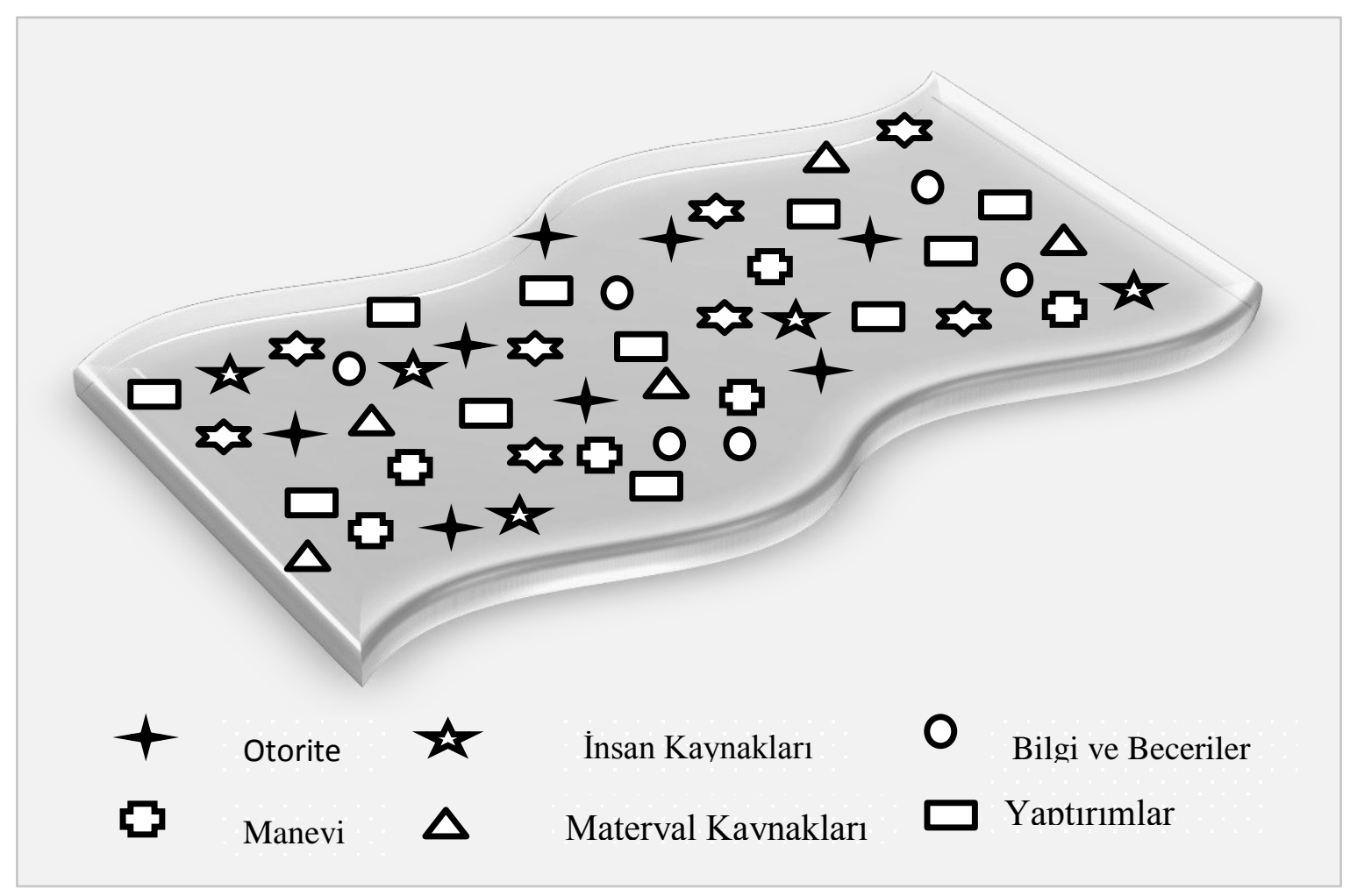

Kaynak: Helvey (2004: 170).

$\mathrm{Bu}$ modelde, devletin en üst kademesinde bulunan kişi ya da grupların sahip olduğu siyasi gücün kaynağının kendileri olmadığı gerçeğini benimsemeleri gerekmektedir. $\mathrm{Bu}$ gücün kaynağı toplumdan gelmektedir. Sahip oldukları siyasi güç tamamen toplumun onlara teslim ettiği güçle doğru orantılıdır. Şekil: 1. 2' de gösterildiği üzere siyasi gücün varlığını devam ettirebilmesi için otorite, insan kaynakları, bilgi ve beceriler, manevi faktörler, materyal kaynakları ve yaptırımlar gibi güç kaynaklarının toplumun farklı kesimlerinden karşılanması gerekmektedir. ${ }^{20}$

Rejimlerin kural koyucu özelliklerini devam ettirebilmeleri için gücün kaynaklarını elverişli hale getirecek kurum ve kuruluşlara ihtiyaçları bulunmaktadır. Sharp tarafından ifade edildiği üzere;

Kural koyucular kendi başlarına vergileri toplayamaz, baskıcı kanun ve yönetmelikleri uygulayamaz, trenlerin zamanında kalkmasını sağlayamaz, ulusal bütçeyi hazırlayamaz, trafiği yönlendiremez, limanları yönetemez, para basamaz,

\footnotetext{
${ }^{20}$ Sharp, Gene; (1973a), Power and Struggle (Politics of Nonviolent Action, Part 1), Porter Sargent Publisher, Boston, s.11
} 
yolları tamir edemez, çelik üretemez, roket yapamaz, ordu ve polisi eğitemez, posta pulu çıkartamaz hatta süt bile sağamaz. İnsanlar çeşitli kurum ve kuruluşlarla bu servisleri kural koyuculara sağlarlar. Eğer bu servisleri sağlamayı keserlerse kural koyucu iktidarı kaybeder. ${ }^{21}$

Her toplum kendine has olsa da, gücün kaynaklarının sağlanması ve gücün yönetilmesi söz konusu olduğunda gerek devlet kurumları gerekse sivil toplum örgütlerinden oluşan destek yapılarına ihtiyaç duyulmaktadır. Başka bir deyişle gücün çoğulcu özelliğini yaratan faktör toplumun genelinden oluşturulan kurum ve kuruluşların varlığıdır. Güç bu yapılara dağılmış durumdadır. Polis, ordu, memurlar, medya, iş camiası, gençler, işçiler, dini kurumlar ve sivil toplum örgütleri gibi yapılar gücün çeşitli kaynaklarını besleyerek siyasi gücü ayakta tutmaktadır.

Gücün dayanakları olan bu kurum ve kuruluşlar sadece iktidara değil, karşı1 gruba da hizmet edebilir. $\mathrm{Bu}$ nedenle otoriter rejimler de karşıt grupların güç yapılarının güçlenmesi ve beslenmesini sınırlandıran faaliyetlerde bulunmaktadırlar. Şiddet içermeyen eylemlerle bir rejimi ortadan kaldırmak ya da siyasi bir değişiklik yapmak hedeflendiğinde gücün dayanaklarının belirlenmesi, analizi ve çok düzeyli bir strateji ortaya konması önemli bir rol oynamaktadır.

Bireylerin itaat ederek, özellikle de gönüllü olarak yerine getirdiği talimat ve emirlere uymaması, kurum ve kuruluşların fonksiyonunu kaybetmesine, bunun sonucu olarak materyal kaynakları güçlü olan rejimler de bile siyasi gücün zedelenmesine veya yer değiştirmesine neden olmaktadır.

Siyasi gücün modelleri, bu gücün kaynakları, kaynakların elde edildiği kurumlar ve son olarak itaat kavramı şiddet içermeyen eylemlerin anlaşılması, planlanması ve istenilen sonucun elde edilmesinde başrolleri oynamaktadır. İtaat, bireylerin eylemlerini siyasi amaçlara bağlayan psikolojik bir mekanizmadır. İnsanların otoriter sisteme boyun eğmesini yatkın kılan sağlamlaştırıcıdır ${ }^{22}$ Bir hükümetin varlığını

\footnotetext{
${ }^{21}$ Sharp, Gene; (1973a), Power and Struggle (Politics of Nonviolent Action, Part 1), Porter Sargent Publisher, Boston.

${ }^{22}$ Milgram, Stanley; (1963), "Behavioral Study of Obedience", http://academic.evergreen.edu/curricular/social_dilemmas/fall/Readings/Week_06/milgram.pdf, 09.03.2015.
} 
devam ettirebilmesi için halkın itaat etmesi ve rıza göstermesi çok önemlidir. İtaat "siyasi gücün kalbidir"23

Emir ve itaat arasındaki ilişki incelendiğinde kural ve kanun gibi yaptırımların oluşturulmasında ve uygulanmasında sadece iktidarın söz sahibi olduğu, gücün yönetilmesinin tek yönlü bir ilişkiye dayandı̆̆ı varsayımı siyasi gücün elde edilmesinde ve kontrolünde itaat ve işbirliği kavramlarının yok sayılması ve sadece yaptırımlar ve cezalar üzerine kurulu bir düzenin varlığının kabul edilmesi anlamını taşımaktadır. Aslında emir ve itaat halk ve iktidar arasındaki iki yönlü ilişkinin derecesini belirleyen karşı1ıklı etkileşimdir. Kural koyucuların baskı ve zorlama imkânları ne kadar güçlü olursa olsun, otoritesinin halk tarafından benimsenmesi gerekmektedir. Bu durum da halkı korku ile yoğurarak değil, insanların istek ve düşüncelerini önemseyerek, zihinlere ulaşmakla sağlanır. Bir rejimin devamlılığı uyum içinde olduğu ve kontrol ettiği toplumsal gücün büyüklüğüyle doğru orantılıdır. Bireyleri itaat etmeye ve boyun eğmeye zorlamak için toplum içinde ciddi rahatsızlık yaratan yaptırımların uygulamaya alınması siyasi gücü elinde bulunduran kural koyucuların otoritenin sağlanmasında kullanılan yöntemlerden biri olmaktadır. Rejimin devamlılığını sağlamak için uygulanan bu yaptırımlar önemli olsa da yeterli değildir. Böyle bir durumda bile rejimin, polis ve ordu gibi kendisine sadık kurumların yardım ve işbirliğine ihtiyacı bulunmaktadır.

\section{2. Şiddet İçermeyen Eylemlerde Mekanizma ve Metotlar}

Şiddet içermeyen eylemler kapsamında arzulanan hedeflerin ulaşılmasında dönüşüm, uzlaşma, şiddet içermeyen baskı ve ayrışma olmak üzere dört değişim mekanizması tanımlanmıştır ${ }^{24}$ Dönüşüm mekanizması, nadiren de olsa iktidarın şiddet içermeyen eylem sonucu tutumunda gönüllü olarak değişiklik yaparak, imtiyaz göstermesi durumunu kapsamaktadır. Ekonomik ve sosyal işbirliğinin geri çekilmesi sonucu iktidarın anlaşmaya varmaya zorlanması uzlaşma mekanizmasını açıklamaktadır.

\footnotetext{
${ }^{23}$ Sharp, Gene; (1973a), Power and Struggle (Politics of Nonviolent Action, Part 1), Porter Sargent Publisher, Boston.

${ }^{24}$ Sharp, Gene; (1985), The Dynamics Of Nonviolent Strugle(Politics of Nonviolent Action, Part 3), Porter Sargent Publisher, Boston.
} 
İktidarın elinde bulundurduğu gücün kaynaklarının yeterince zayıflatıldığı, direnişin güçlü ve yetkin olduğu, bunların sonucu olarak da iktidarın teslim olmaktan başka seçeneğinin bulunmaması durumunu ifade eden mekanizma türü ise şiddet içermeyen baskıdır. Son mekanizma olan ayrışma ise direnişin çok güçlü olduğu, iktidarın güç kaynaklarının tamamen tüketildiği ve var olan sistemin dağılması sürecini içerir. ${ }^{25}$

Şiddet içermeyen mücadeleyle istenilen hedeflere ulaşmak için gerekli koşulların yaratılması şarttır. Geçmişte, şiddete başvurmayan direnişçiler çoğu zaman hedeflerine ulaşmakta başarılı olsalar da, büyük bedeller ödeyerek başarısız oldukları durumlarla da karşı karşıya kalmışlardır. Bu başarısızlıkların direnişçilerin zayıf ve yetersiz olması nedeniyle sindirilerek boyun eğdirilmesi, yanlış metotların seçilmesi ve en önemlisi bir stratejilerinin olmaması gibi çeşitli nedenleri bulunmaktadır. ${ }^{26}$

Şiddet içermeyen eylemlerde her durum kendine özel ve farklı olsa da, başarıya giden yolda dört temel mekanizmadan bahsedilmektedir. Dönüşüm, uzlaşma, şiddet içermeyen baskı ve ayrışma olarak ifade edilen mekanizmalar bazen tek başına bazen de iki veya üçünü içeren kombinasyonlar halinde kullanılmaktadır ${ }^{27}$ Tablo 2.1 mekanizmaların çatışan grupların gücü ile bağlantısını ifade etmektedir.

Şiddet içermeyen mücadele için kavramsal bir yapı sağlayan mekanizmaların her zaman akılda tutulması gerekmektedir. Stratejinin oluşturulması ve planlamanın yapılması sürecinde hangi mekanizmanın ya da mekanizmaların kullanılacağı belirlenirken çatışan grupların güç dengeleri ve kaynakları gözetilmeli, şiddet içermeyen grubun tutum ve hedefleri dikkate alınmalıdır.

Tablo 2. 1: Mekanizma - Güç İlişkisi.

\footnotetext{
${ }^{25}$ Sharp, Gene; (2003), There are Realistic Alternatives, The Albert Einstein Institution, Boston,s.13.

${ }^{26}$ Sharp, Gene; (2005), Waging Nonviolent Struggle: 20th Century Practice and 21 st Century Potential, Boston: Extending Horizons Books,s. 43.

${ }^{27}$ Sharp, Gene; (2010), From Dictatorship to Democracy: A Conceptual Framework for Liberation Fourth Edition, The Albert Einstein Institution, Boston,s.43-44.
} 


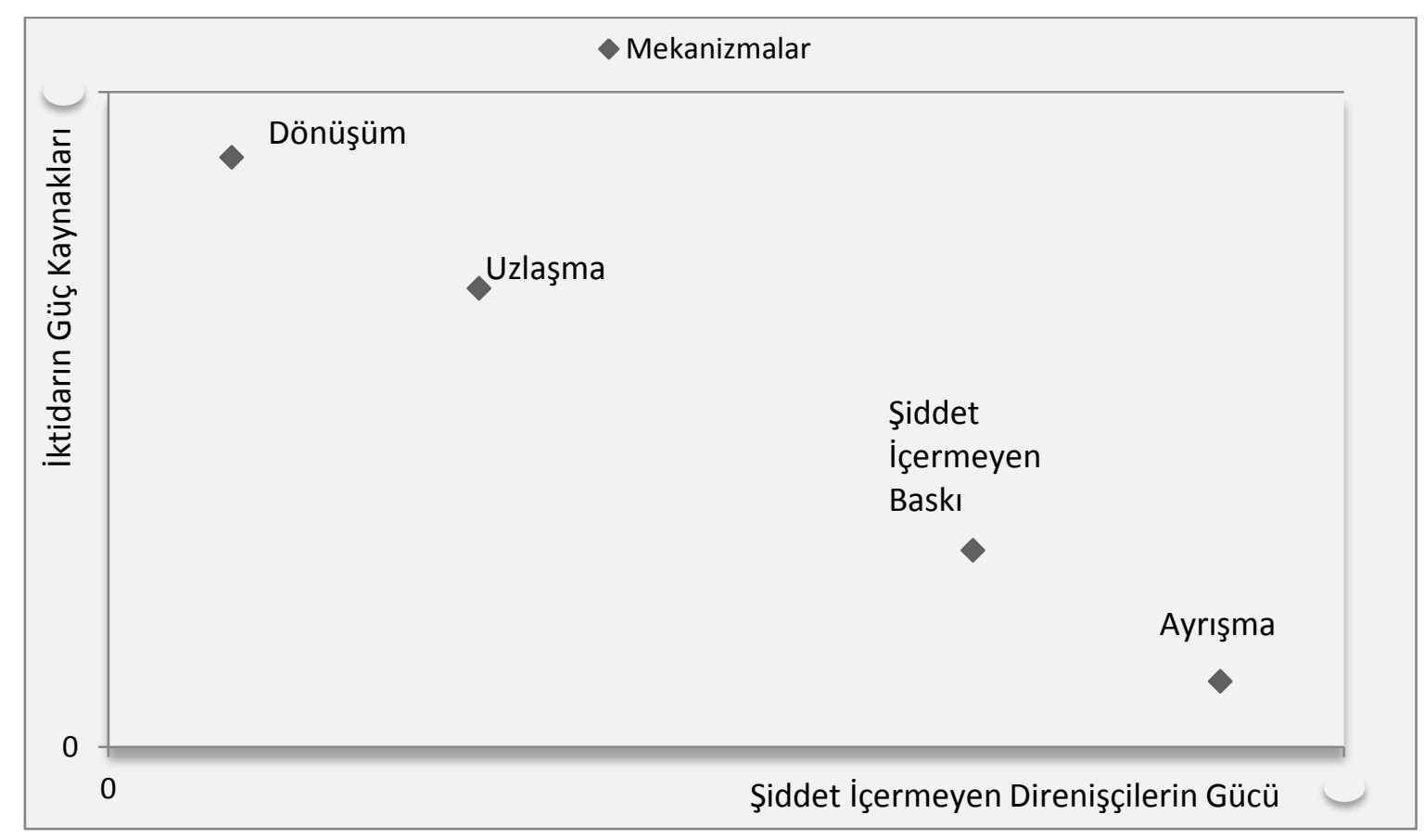

Şiddet içermeyen eylemler, çatışma çözümlerini fiziksel şiddetten uzak kalmayı ilke edinerek ele alan çeşitli metotların şemsiyesi olarak tanımlanmaktadır. Aslında şiddet içermeyen eylemler grev ya da protesto gösterileri gibi birkaç metoda dayandırılarak hazırlıksız ve plansız bir şekilde yürütülen siyasi direnişten fazlasını içermektedir. Bu çatışma tekniğinde Sharp toplam 198 şiddet içermeyen metot tanımlamıştır. ${ }^{28} \mathrm{Bu}$ metotlar şiddet içermeyen protesto ve ikna, direniş ve şiddet içermeyen müdahale olmak üzere üç ana kategori altında sınıflandırılmıştır.

Protesto ve ikna kategorisi yürüyüss, posterler, sokak tiyatroları, el ilanları dağıtma, gece nöbeti ve protesto toplantıları gibi genellikle sembolik olan eylemleri içermektedir. İkinci kategori iktidarla olan mevcut işbirliğinden vazgeçerek direnme yoluna gitmeyi ifade etmektedir. Bu kategorideki metotlar tören ve kutlamalara katılmayı reddetme gibi sosyal boykotları, grevler ya da vergi ödemesi yapmama gibi ekonomik boykotları ve yasama organlarını ya da seçimlere katılmayı reddetme gibi siyasi boykotları içermektedir. Son olarak şiddet içermeyen müdahale ise mevcut sistemin normal işleyişini aksatan psikolojik, sosyal, ekonomik, fiziksel ya da siyasi

\footnotetext{
${ }^{28}$ Sharp, Gene; (1973b), The Methods of Nonviolent Action (Politics of Nonviolent Action, Part 2), Porter Sargent Publisher, Boston.
} 
formlardaki eylemleri içermektedir. İşyerlerinin işgal edilmesi, sokak ve caddelerde oturma eylemleri yapma, açlık grevleri, idari binalara aşırı yüklenilmesi ya da paralel hükümet oluşturma gibi çok farklı şekillerde yapılan şiddet içermeyen müdahale, otoriteye direkt olarak meydan okuma ve çatışmanın çözüme kavuşma olasıllı̆̆ını arttırma firsatı sunmaktadir.

Şiddet içermeyen eylem metotları, yukarıda bahsedilen değişim mekanizmalarını desteklemekte ve bunları yansitmaktadır. Mücadeleci grup tarafindan kullanılan bu metotlar kapsamlı ve çeşitli olabilmektedir. Şiddet içermeyen eylem metotları; "Şiddet İçermeyen Protesto ve İkna" , "Direniş" ve "Şiddet İçermeyen Müdahale" olarak üç ana başlık altında toplanmaktadır. Bu ana başlıklar altında pek çok alt grup yer almaktadır. Gerekli durumlarda bu metotlar içerisinden uygun olanların seçilmesi ve doğru bir şekilde uyarlanabilmesi yaratıcı bir düşünce mekanizması ile mümkün olmaktadir. $^{29}$

Şiddet içermeyen eylem için uygun metotların seçilmesi hangi amaçla kullanılacaklarına göre değişiklik göstermektedir. Bazı durumlarda hareket sahipleri veya organizasyonlar eskiden kullanılan, yeterlilik durumları ispatlanmış olan ya da sadece tercih haklarını kullanarak bazı metotları seçebilir ve bunların uygulanmasını isteyip diğer uygulanabilecek metotları eylemin dışarısında bırakabilirler. Bu durum genel bir tabirle "tersine iş görmek" olarak değerlendirilir. ${ }^{30}$ İdeal olarak yapılması gereken; önce eylem amacının değerlendirilmesi sonrasında ise tüm metotların üzerinden geçilerek stratejik ve taktiksel olarak ortak paydada birleşen metotların seçilmesidir. $\mathrm{Bu}$ değerlendirmenin başlangıç noktasının seçilmesini kolaylaştırmak adına tüm metotlar yukarıda bahsedilen üç ana başlık altında toplanmıştır. ${ }^{31}$

Şiddet içermeyen eylem; gösteri, yürüyüş, oturma eylemi ve grev gibi bilinen ve uygulanan metotların yanı sıra uygulanabilecek pek çok diğer metodu da içerisinde barındırabilecek bir hareket sistemidir. Çoğu mücadelede bilinen metotların tercih

\footnotetext{
${ }^{29}$ Helvey, L. Robert; (2004), On Strategic Nonviolent Conflict : Thinking About The Fundamentals, The Albert Einstein Institution, Boston,s.34.

${ }^{30}$ Helvey, L. Robert; (2004), On Strategic Nonviolent Conflict : Thinking About The Fundamentals, The Albert Einstein Institution, Boston, s.34.

${ }^{31}$ Sharp, Gene; (1973a), Power and Struggle (Politics of Nonviolent Action, Part 1), Porter Sargent Publisher, Boston,s.114.
} 
edilmesi ve diğer metotların değerlendirilmemesi durumu ile karşı karşıya kalınmış, bu durum hareket gücünün boşa harcanması, bıkkınlık ve en önemlisi karşı güçler tarafından bir sonraki eylemin tahmin edilebilirliğinin artması şeklinde sonuçlanmıştır ${ }^{32}$

En iyi bilinen ile başlamak mücadeleci gruplar için optimum başlangıç noktası olarak görünse de kullanılacak metotların genişletilmesi avantajlı durumlar yaratmaktadır. Elbette tüm metotlar kabul edilebilir, uygun ya da kullanışlı değildir. Metotların seçimi esnasında dikkat edilmesi gereken bazı durumlar vardır. Eyleme destek vermesi beklenen kesimin gelenekleri, mücadelede yer alan katılımcı ve mücadele liderlerinin şiddet içermeyen eylem metotları hakkında sahip oldukları bilgi ve birikim, ortamın genel sosyal ve siyasi durumu, mücadele katılımcılarının göz alabilecekleri yıpranma seviyesi, karşıt güçlerin sahip olduğu ve mücadele katılımcıları üzerinde gösterebilecekleri acımasılık seviyesi, mücadele katılımcı sayısı ve bu katılımcıların halk tarafından desteklenme seviyesi ile eylemin sürdürüleceği ortamın fiziksel özellikleri bu durumların bazılarını oluşturmaktadır. ${ }^{33}$

Genel olarak değerlendirildiğinde şiddet içermeyen eylem metotları farkındalık yaratılmadığı sürece sembolik bir etkiye sahip olur. Bu durumu aşmanın en önemli yolu geniş kitlelere ulaşabilmektir. Eylem metotları "Şiddet İçermeyen Protesto ve İkna" , "Direniş" ve "Şiddet İçermeyen Müdahale" ana gruplarında incelendiğinde kullanılan metoda göre kitlelere ulaşmak için farklı yöntemler izlenmesi gerektiği açıkça görülmektedir. ${ }^{34}$

Şiddet içermeyen eylemlerde kullanılacak metotların hangi gruplardan ne şekilde seçileceği konusunda kesin bir yöntem belirlemek mümkün olmamaktadır. Metotlar birbiri ile kıyaslandığında seçim esnasında göz önünde bulundurulabilecek sonuçlar ortaya çıkmaktadır. "Şiddet İçermeyen Protesto ve İkna" metotları kullanıldığında "Şiddet İçermeyen Müdahale" metotlarının kullanılması durumuna kıyasla eylem

\footnotetext{
${ }^{32}$ Miller, Christopher; (2006), "Strategic NonViolent Struggle: Training Manual, University for Peace", http://www.africa.upeace.org/documents/nvtc_Training_Manual.pdf, s. 81, 01.03.2015.

${ }^{33}$ Sharp, Gene; (1973a), Power and Struggle (Politics of Nonviolent Action, Part 1), Porter Sargent Publisher, Boston,s.115.

${ }^{34}$ Sharp, Gene; (1973a), Power and Struggle (Politics of Nonviolent Action, Part 1), Porter Sargent Publisher, Boston,s.114.
} 
yanlılarının rejim ile karşı karşıya geldiklerinde alacakları risk daha az olduğu görülmektedir. "Şiddet İçermeyen Direniş" metotlarını uygulayabilmek için gerekli katılımcı sayısı diğer metotlara göre daha fazladır ancak katılımcıların eğitilmesi durumu dikkate alındığında katılımcı sayısıyla doğru orantılı olarak artma gereksinimi göstermediğinden tercih edilebilirliği daha yüksektir. "Şiddet İçermeyen Müdahale" metotları da katılımcılar tarafından gerekli iç disiplinin ve yüksek ölçüde yıpranma ihtimaline karşı gönüllülügün sağlanması durumunda diğer metotlara göre daha etkili sonuçlara sahiptir.

\section{3. Şiddet İçermeyen Mücadele Stratejisi}

Toplumun itaati, işbirliği ve desteğiyle ayakta duran rejimin ortadan kaldırılmasının en gerçekçi ve elverişli yolu yine toplum içerisinde fillizlenen ve büyüyen toplumsal itaatsizliği şiddet içermeyen eylemlerle somut hale getirmektir. Fakat bunun sağlanmasında belirli bir grubun hazırlıksız ve plansız bir şekilde baskıya ve haksızlıklara karşı koyması, protesto etmesi ve bu eylemlerin yeteri kadar sürdürülürse bu içsel direnişin toplumun tamamını kapsayacak bir sivil itaatsizliğe dönüşeceği varsayımı gerçekçi olmamaktadır. Şiddet içermeyen eylemlerle toplumun tamamını bu direnişe ikna etmek, var olan rejimden kurtulmak ve daha demokratik bir yapıya kavuşmak için gerçekleştirilmesi gereken dört önemli görev bulunmaktadır. ${ }^{35}$

- Bask1 gören toplumun özgüven, karar verme ve direnme yetkinliklerinin artır1mas1,

- Bask1 gören toplumun bağımsız kurum ve kuruluşlarının güçlendirilmesi,

- Güçlü ve içsel bir direnişin yaratılması,

- Mantıklı bir stratejik planın ortaya konması ve uygulanması

Sosyal ya da siyasi mücadelelerin çoğunda bireyler ya da gruplar nasıl hareket edeceklerine dair plan yapmanın önemini bilmektedir. Fakat bu planlar zaman yetersizliği, daha kapsamlı ve uzun vadeli bir planın gereksiz görülmesi gibi

\footnotetext{
${ }^{35}$ Sharp, Gene; (2010), From Dictatorship to Democracy: A Conceptual Framework for Liberation Fourth Edition, The Albert Einstein Institution, Boston,s.15.
} 
nedenlerden dolayı genellikle kısa süreli ve sınırlı olmaktadır. Asıl hedefi işaret eden genel ve kapsamlı bir planın olmaması, izlenecek yol haritasının karşı tarafın inisiyatifine göre şekillenmesine, eldeki güç kaynaklarının israf edilmesine ve yapılan eylemin verimlilikten uzak kalmasına neden olmaktadır.

Stratejik planlama mevcut kaynakların en verimli şekilde kullanılması ve en iyi eylem planının ortaya konması için sistematik bir yaklaşım sağlamaktadır. Direnişçilerin ve rejimin sahip olduğu güç kaynaklarının analizinin yapılması, her iki tarafın güçlü ve zayıf yanlarının belirlenmesi, güç dengesini kendi lehine çevirecek kampanya stratejileri, taktik ve metotların geliştirilmesi materyal kaynakları rejimle kıyaslandığında çok daha kısıtlı ve destekçileri tehlike altında olan demokrasi yanlısı direnişçiler için yerine getirilmesi gereken unsurlardır.

Stratejik planlama, askeri operasyonlarda ne kadar önemliyse şiddet içermeyen eylemlerde de aynı öneme sahiptir. ${ }^{36}$ Her ikisinde de mevcut imkânlardan ve çatışmanın sürekli değişen dinamiklerinden maksimum düzeyde faydalanma amaçlanmaktadır. Eylem şiddet içersin ya da içermesin zamanın verimli kullanılması ve rakip üzerinde psikolojik üstünlük sağlanması gibi faktörler çatışmalarda kilit noktaları oluşturmaktadır.

Tarihte, şiddet içermeyen eylemlerin stratejik kullanımının başarı getirdiği birçok örnek bulunmaktadır. Sovyetler birliğine bağlı iken Naziler tarafından işgal edilen, sonrasında Sovyetler birliğinden ayrılan üç küçük Baltık ülkesi olan Litvanya, Letonya ve Estonya'nın 1991 yılında sonuçlanan özgürlük mücadelesi ve 1990 döneminin sonundaki Sırbistan'ın Miloseviç rejiminden kurtulma mücadelesi yakın tarihteki en önemli örneklerdir. Bahsi geçen dört ülkenin verilen mücadele açısından genel özellikleri ; ${ }^{37}$

- Baskıcı ve zalim rejimlere maruz kalınması,

\footnotetext{
${ }^{36}$ Sharp, Gene; (1985), The Dynamics Of Nonviolent Strugle(Politics of Nonviolent Action, Part 3), Porter Sargent Publisher, Boston,493.

${ }^{37}$ Sharp, Gene ve J. Raqib; (2009), Self-Liberation: A Guide to Strategic Planning for Action to End a Dictatorship or Other Oppression, The Albert Einstein Institution, Boston,s.34.
} 
- Mücadelenin ilk yıllarında şiddet içeren eylemlerin yapılması, fakat başarısız olunmas1,

- Şiddet içeren eylemleri takip eden süreçte plan ve stratejisi olmayan önemli iç kaynaklı protesto ve gösterilerin yapılması,

- Şiddet içermeyen eylemler ve strateji konularında danışmanlık ve seminer faaliyetleri gerçekleştirilmesi sonucunda yürütülen sistematik bir mücadele sonucu mevcut rejimlerin ortadan kaldırılması olarak ifade edilebilir.

Direniş güç kaynaklarını artırmak, diktatörlük rejimini sonlandırmak ve ardından daha demokratik bir siyasi yapı inşa etmek için kapsamlı bir analiz ve hareket planının varlığı önem taşımaktadır. Verilecek mücadelede harekete geçmeden önce amaca götürecek genel stratejinin ortaya konmas1, genel stratejiyi besleyecek kampanya stratejilerinin belirlenmesi ve izlenecek metotların açıça belirtilmesi gerekmektedir.

Genel strateji, grubun var olan çatışmadaki amaçları ve güç kaynaklarını göz önünde tutarak en uygun hareket biçimini (Askeri harp, şiddet içermeyen eylem vb.) belirleyen aşamadır. Genel strateji en uygun koşul ve zamanlamanın değerlendirilerek ilk ve daha sonra gerçekleşecek kampanyaların ne zaman işleme alınacağı kararlarını içermektedir. ${ }^{38}$ Başka bir deyişle mücadele kapsamında işletilecek belirli stratejiler için temel bir iskelet oluşturmaktadır. Ayrıca grubun organizasyon yapısı, görev dağılımları ve var olan kaynakların grup içinde nasıl dağıtılacağı genel stratejide belirlenmektedir.

Genel stratejinin açık ve kesin bir şekilde oluşturulmasında aşağıda belirtilen konuların analizinin yapılması gerekmektedir. ${ }^{39}$

- Çatışan grupların güçlü ve zayıf yanları nelerdir?

- Hangi durumlar için harekete geçmek öncelik içermektedir?

- Sorunlar ve olası baskı güçleri örtüşmekte midir?

\footnotetext{
${ }^{38}$ Sharp, Gene; (2010), From Dictatorship to Democracy: A Conceptual Framework for Liberation Fourth Edition, The Albert Einstein Institution, Boston,s.43

${ }^{39}$ Sharp, Gene ve J. Raqib; (2009), Self-Liberation: A Guide to Strategic Planning for Action to End a Dictatorship or Other Oppression, The Albert Einstein Institution, Boston,s.34.
} 
- Direnişçilerin erişebileceği baskı güçlerinin, ana stratejilerinin şekillenmesi ile ilişkisi nedir?

- Direnişçilerin erişebileceği baskı güçleri, rejimin zayıflıkları ile nasıl ilişkilendirilir?

- Rejimin hangi dayanakları direnişçilerin erişebileceği baskı güçlerinin uygulanması durumunda potansiyel olarak savunmasız durumdadır?

Organizasyon yapısının şekillenmesi, durum değerlendirmesi, hedefe götürecek araçların seçimi, dış yardımların mücadeledeki rolünün saptanması aşamalarından sonra ana hatlarıyla oluşturulan genel strateji daha özgür ve demokratik bir sistem için formül niteliği taşımaktadır.

Genel strateji oluşturulduktan sonraki süreçte planın genel hatlarının toplumla paylaşılmasının birçok yararı bulunmaktadır. Mücadelenin genel konsepti anlaşıldığında toplumda moral açısından pozitif etkilerin oluşması ve aktif direnişe gönüllü olarak katılan insan sayısının artması sağlanabilmektedir. Genel konseptin rejim tarafından bilinmesi de direnişçiler tarafından yapılan eylemlerde rejimin şiddet uygulama konusunda daha dikkatli olmasını, baskı ve şiddetin siyasi olarak kendisine zarar vereceğini algılamasını sağlamaktadır. Mücadelenin genel özelliklerinin bilinmesi rejim dayanaklarında da ayrışmalara ve taraf değiştirmelere neden olabilmektedir. ${ }^{40}$

Kampanya stratejisi, genel strateji çerçevesinde belirlenen hedeflere en iyi ve verimli şekilde nasıl ulaşılacağını belirleyen konsepttir. Kampanyanın nasıl gerçekleştirileceği ve hangi kaynakların kullanılacağı konularını içeren bu aşama, birçok metodun hünerli bir şekilde harmanlandığı grup eylem planlarından oluşur. Kampanya stratejilerinde seçilen mücadele tekniklerinin başarısının genel stratejiye katkısının değerlendirilmesi, gereksiz kaynak kullanımı ve zaman kaybı gibi olumsuzlukların ortadan kaldırılması için çok önemlidir. Kampanya stratejisi oluşturulurken kampanya amaçlarının net olarak belirlenmesi ve bu amaçları gerçekleştirmek için gerekli olan kaynağın nasıl ölçüleceğinin saptanması her bir

\footnotetext{
${ }^{40}$ Sharp, Gene; (2010), From Dictatorship to Democracy: A Conceptual Framework for Liberation Fourth Edition, The Albert Einstein Institution, Boston,s.52
} 
amacın güvence altına alınmasında kullanılacak gereksinimlerin tanımlanmasına olanak sağlamaktadır . ${ }^{41}$

Kampanyaların strateji planlamasında direnişçilerin aşağıda belirtilen konuları dikkate alması, kampanyanın başarı oranının artırılması ve genel stratejiye katkısının sağlanması için önem taşımaktadır. ${ }^{42}$

- Kampanyaya özgü amaçlar ve genel stratejinin uygulanmasına olan katkıların belirlenmesi.

- Kampanyanın en iyi şekilde uygulanmasını sağlayacak metotların değerlendirilmesi ve seçilen metotların rejimin güç kaynakları üzerinde nasıl bir baskı ve kısıtlama getireceğinin belirlenmesi.

- Uygulanacak kampanyanın ülke ekonomisini etkileyerek rejime bask1 yapması amaçlanıyorsa, rejimin sonlanmasını takip eden süreçte yaratılan ekonomik sıkıntıların giderilebilir olmasının değerlendirilmesi. (Aksi halde toplum gözünde oluşan hayal kırıklığı ve hoşnutsuzluk demokratik sistemin oluşturulmasını olumsuz yönde etkileyebilmekte ve ekonomik sıkıntıları sonlandıracağı vaadini veren başka bir diktatörün iktidara gelmesine yol açabilmektedir.)

- Direnişle ilgili haberlerin toplum, rejim güç dayanakları ve uluslararası çevre ile paylaşılması ve mücadelenin toplum gözünde güvenirliğinin yitirilmemesi için sunulan bildiri ve raporların doğruluğundan emin olunması.

- Kampanya süresince direnişçilerin ihtiyaçlarını karşılamak amacıyla özgüven arttırıcı sosyal, ekonomik ve siyasi aktiviteler düzenlenmesi

- Uygulanacak kampanyada dişsal desteğin planlanması ve sivil toplum örgütleri, hükümetler ya da Birleşmiş Milletler gibi kurum ve kuruluşlardan hangisinin yardımının en uygun olduğunun belirlenmesi.

Mücadelenin ilk dönemlerinde her biri ayrı amaca hizmet eden farklı kampanyaların eş zamanlı yürütülmesi önem taşımaktadır. Seçici direniş olarak belirtilen bu

\footnotetext{
${ }^{41}$ Sharp, Gene; (2010), From Dictatorship to Democracy: A Conceptual Framework for Liberation Fourth Edition, The Albert Einstein Institution, Boston,s.47

${ }^{42}$ Sharp, Gene; (2010), From Dictatorship to Democracy: A Conceptual Framework for Liberation Fourth Edition, The Albert Einstein Institution, Boston,s.60-70.
} 
kampanya stratejisinde seçilen konuların toplumun belirli bir sıkıntısına hitap etmesi gerekmektedir. ${ }^{43} \mathrm{Bu}$ ara amaçların direnişin mevcut güç kapasitesi ile doğru orantılı olmasıyla gelecek başarı serileri hem direnişçi gruba moral açısından olumlu etkiler sağlaması hem de mücadelenin ana amaçları için gerekli olan güç kaynaklarının yön değiştirmesine katkıda bulunması açısından önem taşımaktadır. Seçici direniş konularının mevcut sistemin bir parçasını rejimden ayırmak, rejimin belirli bir konudaki kararını reddetmek gibi sosyal, ekonomik ya da siyasi içerikte olması ara amacın güç kapasitesine olan pozitif etkilerini arttırmaktadır.

Kampanya stratejileri pozitif ve negatif olmak üzere iki ana kategoriden oluşmaktadır. ${ }^{44}$ Negatif kampanyalar otorite tarafından gerçekleştirilen uygulama, anlaşma, yasa ya da politikalara karşı yürütüleceği gibi direkt olarak otoritenin varlığını da hedef alabilmektedir. Negatif kampanyalar karşı olan düşüncenin ya da kişinin net olarak teşhir edilmesini ve meşruluğunun sorgulanmasını sağlamasına karşın direnişçi grup için geçici bir dayanışma ve birliktelik ortamı sağlamaktadır. Pozitif kampanyalar ise baskı görmüş ve haksızlığa uğramış toplumun desteğini oluşturmakla beraber görüş ayrılığı yaşayan ya da önceden tarafsız olan grupları belli bir ortak hedef üzerinde toplayarak, bu gruplar arasında bağ kurulmasını amaçlamaktadır. $\mathrm{Bu}$ nedenle şiddet içermeyen mücadele ile bir rejimin sonlandırılması ve yerine daha demokratik bir sistemin getirilmesi amaçlanıyorsa negatif ve pozitif kampanyaların her ikisinin de dikkate alınması gerekmektedir.

Rejimin güç kaynaklarının işlevselliğini ortadan kaldırmak taraflar arasındaki güç dengesizliğinden dolayı ilk zamanlarda çok zordur. Rejimin reddedilmesi amacını güden toplu ve güçlü bir direnişle karşı koymak için rejime itaat eden halkın büyük bir kısmının ve sivil toplum örgütlerinin desteğini ihtiyaç duyulmaktadır. Mevcut durumda bu şartlar sağlanmadığından yürütülecek kampanyaların grubun gücüyle doğru orantılı sembolik anlamlar içermesi gerekmektedir. Örneğin önemli olan bir yere çiçek bırakma, kısa bir süre için işleri askıya alma ya da belli bir süre sessiz kalarak konuşmama gibi sembolik protesto ve direnme eylemleri halkın bu mücadele

\footnotetext{
${ }^{43}$ Sharp, Gene; (2010), From Dictatorship to Democracy: A Conceptual Framework for Liberation Fourth Edition, The Albert Einstein Institution, Boston, s.59.

${ }_{44}$ Miller, Christopher; (2006), "Strategic NonViolent Struggle: Training Manual, University for Peace", http://www.africa.upeace.org/documents/nvtc_Training_Manual.pdf, 01.03.2015.
} 
için bakış açısını test etme ve gözlemleme bakımından öneme sahiptir ${ }^{45}$ (Sharp, 2003: 14).

Belirlenmiş kampanya stratejilerinin herhangi bir bölümünde kullanılacak olan metot seçimleri, mücadele araçlarından en etkin şekilde fayda sağlanması için daimi dikkatle yapılmalı, sonucun kampanya stratejisinin amacını beslemesi gerekliliği göz ardı edilmemelidir. Metot seçimlerinde mücadeleci grup ve rejim arasındaki güç dengesinin ne durumda olduğunun ve metodun uygulanması sirasında ve sonrasında grubun rejim tarafından yapılacak baskı ve şiddete dayanıklılı̆̆ının değerlendirilmesi gerekmektedir.

\section{Sonuç}

Şiddet içermeyen mücadele, şiddet kullanımını reddeden bir çatışma tekniğidir. Toplumdaki her bireyin katılabileceği, daha demokratik ve özgürlükçü bir sisteme sahip olmak gibi barışçıl amaçlar taşıyan ve bu amaca ulaşıldığında sadece mücadele edenlerin değil toplumun tamamı için yarar gözeten bu teknik şiddet içeren muadillerine göre çatışmanın çözümlenmesini izleyen süreçte daha efektif ve yapıcı getirilere sahiptir.

Her iktidar toplumun itaati, işbirliği ve desteğiyle varlığını sürdürmekte ve siyasi gücü elinde bulundurmaktadır. Toplum bu işbirliğinden vazgeçerek desteğini esirgediğinde kural koyucu etki ve itibarını devam ettirecek dayanaklardan yoksun kalmaktadır. Toplumun çeşitli kesimlerinden karşılanan güç kaynakları olmadan kural koyucunun meşrutiyetinden bahsedilemez.

Şiddet içermeyen eylemlerde strateji kullanımı, başarıya ulaşmak için üzerinde çok durulması ve dikkate alınması gereken bir konudur. İyi analiz edilmiş ve planlanmış bir strateji bu tekniğin etkin olarak kullanılmasını sağlamaktadır. Şiddet içermeyen mücadelenin ihtiyaç duyduğu güç kaynaklarını artırmak, diktatörlük rejimini sonlandırmak ve ardından daha demokratik bir siyasi yapı inşa etmek için kapsamlı bir analiz ve hareket planını içeren mücadele stratejisinin ortaya konması önem

\footnotetext{
${ }^{45}$ Sharp, Gene; (2003), There are Realistic Alternatives, The Albert Einstein Institution, Boston,s.14.
} 
taşımaktadır. Bu stratejik plan değişim mekanizmalarının işletilmesi için gerekli olan kritik kitleyi gözetmeli ve uygulanacak şiddet içermeyen metotlar bu amaca hizmet etmelidir.

Şiddet içermeyen eylemler toplumsal bir çaba ve şiddete başvurmamayı gerektiren sağlam bir disiplin anlayışını gerektirmektedir. Bu tekniği benimseyen mücadeleci grubun çatışma çözümünün uzun vadeli olacağının ve çoğu zaman da mevcut rejim tarafından baskı ve zulümle karşılık verileceğinin farkında olması önem taşımaktadır. Tarihçi ve yazar Theodore Roszak'ın “Insanlar şiddet içermeyen eylemleri bir hafta dener ve işe yaramadiğında, yüzyıllardır işe yaramayan şiddete tekrar geri dönerler" sözü şiddetin çatışmalarda çözüm getirmeyeceğinin ve şiddet içermeyen mücadelenin zorluklara tahammül gösterme ve sebat etme disiplinine dayandığının özeti niteliğindedir.

\section{Kaynakça}

Birdişli, Fikret; (2013), "Şiddet İçermeyen Eylemler ve Ulusal Güvenlik”, 118

Dağcı, Kenan ve Efe Çaman; (2012), "Uluslararası Çatışma Çözümleri Yaklaşımları: Müzakere ve Arabuluculuk" / "Conflict Resolution Approaches: Negotiation And Mediation”, International Joint Conference, 10th (Int.) Knowledge Economy and Management Congress, Istanbul.

Guardian; 2015, "British army creates team of Facebook warriors", http://www.theguardian.com/uk-news/2015/jan/31/british-army-facebook-warriors77th-brigade, 20.02.2015.

Helvey, L. Robert; (2004), On Strategic Nonviolent Conflict : Thinking About The Fundamentals, The Albert Einstein Institution, Boston.

Gandhi, Mahatma; (1955), "My Religion”, http://www.mkgandhi.org/ebks/my_religion.pdf, 08.03.2015.

Kuzio, Taras; (2006), "Communist and Post-Communist Studies", 
http://www.elsevier.com/locate/postcomstud, 05.03.2015.

Milgram, Stanley; (1963), "Behavioral Study of Obedience", http://academic.evergreen.edu/curricular/social_dilemmas/fall/Readings/Week_06/m ilgram.pdf, 09.03.2015.

Miller, Christopher; (2006), "Strategic NonViolent Struggle: Training Manual, University for Peace", http://www.africa.upeace.org/documents/nvtc_Training_Manual.pdf, 01.03.2015.

Popovic, S.,M. Andrej ve D. Slobodan; (2006), "Nonviolent Struggle : 50 Crucial Points", http://www.canvasopedia.org/images/books/50-Crucial-Points/NonViolentStruggle-50-CP-book-small.pdf?pdf=50CP-ENG, 09.03.2015.

Sharp, Gene; (1973a), Power and Struggle (Politics of Nonviolent Action, Part 1), Porter Sargent Publisher, Boston.

Sharp, Gene; (1973b), The Methods of Nonviolent Action (Politics of Nonviolent Action, Part 2), Porter Sargent Publisher, Boston.

Sharp, Gene; (1985), The Dynamics Of Nonviolent Strugle(Politics of Nonviolent Action, Part 3), Porter Sargent Publisher, Boston.

Sharp, Gene; (2003), There are Realistic Alternatives, The Albert Einstein Institution, Boston

Sharp, Gene ve B. Jenkins; (2003), The Anti-Coup, The Albert Einstein Institution, Boston.

Sharp, Gene; (2005), Waging Nonviolent Struggle: 20th Century Practice and 21st Century Potential, Boston: Extending Horizons Books.

Sharp, Gene ve J. Raqib; (2009), Self-Liberation: A Guide to Strategic Planning for Action to End a Dictatorship or Other Oppression, The Albert Einstein Institution, Boston. 
Sharp, Gene; (2010), From Dictatorship to Democracy: A Conceptual Framework for Liberation Fourth Edition, The Albert Einstein Institution, Boston.

Tonkin, Derek; (2004), “The 1990 Elections in Myanmar (Burma): Broken Promises or a Failure of Communications?", http://www.ibiblio.org/obl/docs/DTElections.html, 02.03.2015

Weissman, Steve; (2009), "How Washington Learned to Love Nonviolence", http://theragblog.blogspot.com.tr/2009/09/steve-weissman-how-washingtonlearned.html, 27.02.2015. 